WittLer, R. G. (1952). J. gen. Microbiol. 6, 311-317.

\title{
The L-Form of Haemophilus pertussis in the Mouse
}

\author{
BY RUTH G. WITTLER* \\ Lister Institute of Preventive Medicine, London
}

SUMMARY: An examination of Giemsa-stained preparations of lung tissue and peritoneal fluid from mice inoculated with Haemophilus pertussis shows that the bacillary form can change to the $\mathbf{L}$-form of the organism in vivo. This transformation is more rapid and more complete in immune than in normal mice. The L-form, produced on Bordet-Gengou agar containing $1.5 \%(w / v)$ glycine, administered intranasally can revert to the bacillary form in vivo.

Only two reports have been found in the literature on the isolation of L-forms of pathogenic bacteria directly from an animal or from a human being. The first (Klieneberger, 1938) was the L-form of Streptobacillus moniliformis, Strain ' 59 lung' found as an independent organism (not associated with a bacillus) in the lung lesions of a rat. At the time of this report, Klieneberger described the organism as the L1 'symbiont' of Strep. moniliformis, but she has since changed her views and now regards the $L 1$ as a growth phase of the bacillus (Klieneberger-Nobel, 1949). The second (Dienes \& Smith, 1944) was the L-form of a Bacteroides sp. strain 'O.H.', 'cultivated from pus accumulated in the peritoneal cavity following infection of the Fallopian tubes'. However, the authors themselves were in some doubt whether this organism was really in its L-form in the host, and they discuss their reasons for and against believing that the $\mathbf{L}$-form was present in the pus.

In order to gain an understanding of the significance of the L-form, one of the many questions that must be answered is, 'Does the L-form of pathogenic bacteria occur in vivo with any degree of regularity, and if so under what conditions?' The present study was undertaken in an effort to obtain an answer to this question.

\section{MATERIALS AND METHODS}

Mice. All mice used weighed between 17 and $20 \mathrm{~g}$. and were chosen from an English strain, 'Cl.' or an American strain, 'N.I.H.'.

Strains. A smooth strain of Haemophilus pertussis, No. 19939, with a high mouse virulence, was used for infection and challenge of mice. Various smooth strains of $H$. pertussis were used for immunization.

Preparation of suspensions. The bacillary form was grown on $30 \%$ horse blood Bordet-Gengou (BG) medium and the L-form on BG containing $1.5 \%$ $(\mathrm{w} / \mathrm{v})$ glycine. The $20 \mathrm{hr}$. growth was scraped off into $1 \%$ Bacto-Casamino acids and suspensions were standardized against Brown's] Opacity Tubes (Burroughs Wellcome and Co. Ltd., London) assuming that $\boldsymbol{H}$. pertussis was equivalent to $H$. influenzae.

* Present address: Institute of Pathology, Western Reserve University, Cleveland 6, Ohio, U.S.A. 
Mice chosen for autopsy. During the first 3 days after inoculation, mice that were apparently well were chosen at random. After the majority of mice had begun to show some signs of illness, the ones that appeared most ill were chosen. Dead mice were not examined because of the presence of contaminants in their tissues.

Control uninoculated mice were also killed and examined for the presence of organisms by the methods used for inoculated mice.

Preparation and cultivation of autopsy material. Immediately after killing a mouse, a portion of its lungs was grasped in a pair of forceps and dragged back and forth over the whole surface of several BG plates, the tissue being squeezed to express some of the fluid. Peritoneal fluid was examined by opening the peritoneal cavity and rinsing with a few drops of $1 \%$ BactoCasamino acids. The fluid was collected in a capillary pipette and spread on BG plates. Plates were incubated at $35^{\circ}$.

Autopsy material and subcultures from autopsy material were never planted on media containing glycine, penicillin, nor any other substance that might stimulate the production of $\mathbf{L}$-forms.

Preparation of slides. Coverslip impression preparations were made from squares of agar cut from the plate cultures immediately after inoculating the plates (0 hr.), and after 3-5, 24, $48 \mathrm{hr}$., and sometimes $72 \mathrm{hr}$. of incubation. The 3-5 hr. preparations were useful in the detection of contaminations which were often overlooked in $\mathbf{0 ~ h r}$. preparations. Since it is essential in experiments of this type that all preparations be absolutely free of contaminating organisms, all contaminated cultures were immediately discarded. The 48-72 hr. preparations acted as a check on the $24 \mathrm{hr}$. Furthermore, adequate growth for agglutination tests could often be obtained only after $48 \mathrm{hr}$. incubation. The impression preparations were fixed, treated, and stained with Giemsa according to methods already described (Klieneberger-Nobel, 1950; Wittler, 1951).

\section{EXPERIMENTAL}

Intranasal inoculation of normal mice with the $L$-form

Mice, inoculated intranasally with the L-form of $\boldsymbol{H}$. pertussis (produced by growth on BG-glycine agar), were killed at various times between the second and twenty-fourth day following inoculation. Lung cultures and impression preparations were made. All except one of the inoculated mice yielded bacilli and occasional small round red forms. Even the $0 \mathrm{hr}$. preparations, although there were always at least a few L-bodies present, showed predominantly blue bacillary forms. However, one mouse, killed on the 14th day after inoculation, yielded L-forms. Its lungs showed patches of consolidation, but their gross appearance was in no way distinct from any that had been encountered earlier. The $0 \mathrm{hr}$. impression preparations showed that all the organisms were in the granular stage of the L-cycle (Pl. 1, fig. 1) or in the amorphous stage consisting of shapeless cytoplasmic masses without definite cell walls, in which the nuclear material was dispersed in a variety of patterns. The $3 \mathrm{hr}$. preparations showed a slight increase in the amount of L-material (Pl. 1, fig. 2) and the 
$24 \mathrm{hr}$. ones a very great increase (PI. 1, fig. 3), but still no bacilli could be found. The $48 \mathrm{hr}$. Giemsa-stained preparations showed masses of amorphous L-material among which were patches of dark red or purple bodies that were dividing up into bacilli (Pl. 2, fig. 4), as well as many patches of large purple or very pale blue bacilli.

Subcultures made from the $24 \mathrm{hr}$. growth to fresh BG medium followed the same developmental pattern as the original plates, and after $48 \mathrm{hr}$. of incubation bacilli were appearing in masses of amorphous L-material (Pl. 2, fig. 5). The second subculture, made from the $72 \mathrm{hr}$. growth of the first subculture, showed an almost pure growth of the bacillary form which agglutinated strongly with undiluted Phase 1 pertussis antiserum (Pl. 2, fig. 6). This culture was then put through five serial passages on ordinary BG. It remained completely in the bacillary form. When inoculated intranasally into mice, it had the same virulence as the mother culture (bacillary) from which it had originally been derived.

The results of this experiment offered two possible explanations. Either the L-form when injected into mice ( $a$ ) always reverted to the bacillary form, but on occasion could change back into the L-form again, or $(b)$ usually reverted to the bacillary form, but on occasion could remain in the L-form. The next step was to investigate whether the bacillary form could change into the L-form in vivo.

\section{Intranasal inoculation of normal mice with the bacillary form}

Normal mice were inoculated intranasally with bacilli in doses roughly equivalent to the dose of $\mathbf{L}$-forms given in the previous experiment. Mice were killed at various times between $2 \mathrm{hr}$. and 15 days. Portions of the lungs were wiped over BG plates and impression preparations taken. The following observations were made.

Mice killed 2-4 hr. after inoculation. $0 \mathrm{hr}$. preparations. Most of the organisms were blue bacilli in an extracellular position. Occasional small round red forms were present in phagocytic cells. 24 $h r$. preparations. Heavy bacillary growth. No evidence that the organisms had passed through the stages of the L-cycle.

Mice killed 1-2 days after inoculation. 0 hr. preparations. Some showed the same results as the mice killed 2-4 hr. after inoculation. Others showed a great many small round red forms in phagocytic cells. 24 $h r$. preparations. Heavy bacillary growth. Some organisms which were intracellular or else located in small colonies overgrowing phagocytic cells were in the various L-forms and stained either bright red or very pale blue.

Mice killed 6-7 days after inoculation. $0 \mathrm{hr}$. preparations. Most organisms were red, pleomorphic or granular forms located in phagocytic cells. Extracellular organisms were usually blue bacilli. 24 $h r$. preparations. Same as the 1-2 days, 24 hr. preparations except more L-forms present.

Mice killed 12-15 days after inoculation. $0 \mathrm{hr}$. preparations. Organisms observed were all intracellular, and were in tissue cells as well as phagocytic cells. They were either small round red forms or pale blue pleomorphic forms. 
There was much pale blue or bright red amorphous material in the background which could not be identified with certainty as L-material. 24 hr.preparations. Many L-forms, large bodies, and small round red forms present in and around cells and tissues. Heavy growth of red or blue bacilli as well.

The number of L-forms appeared to increase with the duration of the infection, which suggested that the change to the L-form might be taking place as a response to an environment that was becoming increasingly less favourable. Since Dienes, Weinberger \& Madoff (1950) had shown that, at least in vitro, various strains of Salmonella changed into the L-form when exposed to immune serum and complement, it seemed possible that the development of immunity in the host might be the stimulus inducing the transformation of $\boldsymbol{H}$. pertussis in vivo.

\section{Intranasal inoculation of immune mice with the bacillary form}

Mice were immunized intraperitoneally with living or formalized $\boldsymbol{H}$. pertussis bacilli with doses ranging from $2000 \times 10^{6}$ to $80 \times 10^{6}$ organisms/mouse. After a rest period of 10 days to 5 weeks, mice were challenged intranasally and were killed at various times between $2 \mathrm{hr}$. and 18 days thereafter. Portions of lung were wiped over BG plates and impression preparations made as before. The majority of the normal control mice which were challenged died within 3 to 7 days.

Mice killed 2-4 hr. after challenge. $0 \mathrm{hr}$. preparations. Most of the organisms were blue bacilli in an extracellular position. Occasional small round red forms were present in phagocytic cells. $24 \mathrm{hr}$. preparations. Heavy bacillary growth. No evidence that the organisms had passed through the stages of the L-cycle.

Mice killed 1-2 days after challenge. $0 \mathrm{hr}$. preparations. Nearly all the organisms found were located intracellularly. Red organisms were small round forms, granules, or minute bacilli. Blue organisms were very pale and very pleomorphic. 24 hr. preparations. Many stages of the L-cycle present intracellularly and extracellularly. Numerous blue, red, and purple bacilli present extracellularly.

Mice killed 4-7 days after challenge. $0 \mathrm{hr}$. preparations. All organisms were in the granular or amorphous stages of the L-cycle and located both intracellularly and extracellularly. 24 $h r$. preparations. All stages of the L-cycle were still present. A few bacilli were appearing at the periphery of masses of amorphous L-material. (Photographs of preparations from this group of mice were almost identical with the series shown in Pls. I and 2, figs. 1-6, except that the reversion to bacillary form occurred slightly sooner.)

Mice killed 14-18 days after challenge. $0 \mathrm{hr}$. preparations. Some animals showed only the granular and amorphous stages of the L-cycle. Others showed only the small round red form. 24 $h r$. preparations. Development varied according to the stage in which the organisms were isolated.

It was observed that the rapidity and completeness of the transformation to the L-form varied with the degree of immunity in the mouse. Those mice that had received an adequate immunizing dose $\left(2000 \times 10^{6}\right.$ organisms/mouse) followed by a 10-day to 3-week rest period yielded pure L-cultures on the 
fourth to seventh day after challenge. The mice that had received the smallest immunizing doses $\left(80 \times 10^{6}\right.$ organisms/mouse) followed by a long rest period yielded a mixture of $\mathrm{L}$ - and bacillary forms at this time as did the normal mice. However, 14-18 days after challenge even these mice yielded pure L-cultures. The most striking difference between immune and normal animals was the rapidity of phagocytosis, the immune ones showing more complete phagocytosis in 2 days than the normal ones did in 7 days. Furthermore, the extent of transformation to the L-form appeared to vary directly with the extent of phagocytosis. From these experiments it appeared that immunity in the mouse promoted the L-transformation.

\section{Intraperitoneal inoculation of normal mice with the bacillary form}

The peritoneum of the mouse is not a site favourable for the establishment of infection with $\boldsymbol{H}$. pertussis. Small doses of the organism have little effect on the mouse while large doses produce rapid death from toxin. It was considered worthwhile, however, to investigate the behaviour of $\boldsymbol{H}$. pertussis in this environment. Moderate doses of the bacillary form were injected into mice which were sacrificed at various times from $2 \mathrm{hr}$. to 7 days later. Cultures of the peritoneal fluid were made and impression preparations examined.

Mice killed 2 hr. after inoculation. 0 hr. preparations. About half the organisms were small round red forms or very pleomorphic pale blue forms in an intracellular position. Extracellular organisms were ordinary bacilli. 24 $h r$. preparations. Frequent small L-bodies as well as the small round red form were present intracellularly. Very numerous ordinary bacilli and a few small round red forms were present extracellularly.

Mice killed 1 day after inoculation. $0 \mathrm{hr}$. preparations. Nearly all organisms found were intracellular and in the small round red form. 24 hr.preparations. Small red form still present intracellularly, but many thin long bacilli were also present extracellularly.

Mice killed 6-7 days after inoculation. $0 \mathrm{hr}$. preparations. Minute round red forms in an intracellular position. No bacilli observed. 24 hr. preparations. Growth very slow. Size of red forms had increased slightly. Moderate number of pale blue, round or pleomorphic forms and a very few bacilli.

In normal mice phagocytosis was more prominent and rapid in the peritoneum than in the lung. As noted before, there appeared to be some correlation between phagocytosis and rapidity of transformation to the L-form. Therefore, although much the same sequence of events occurred in the peritoneum as in the lung, the transformation to the L-form was accelerated in the peritoneum.

\section{Intraperitoneal inoculation of immunized mice with the bacillary form}

The experiment was repeated using immunized mice. Mice were immunized with living or formalized bacilli with doses ranging from $2000 \times 10^{6}$ to $100 \times 10^{6}$. The rest period before challenge was 4-5 weeks.

Mice killed $2 \mathrm{hr}$. after challenge. $0 \mathrm{hr}$. preparations. Nearly all the organisms observed were intracellular and in the small round red form or very 
pleomorphic pale blue forms. $24 \mathrm{hr}$. preparations. Numerous large L-bodies and great numbers of small red forms both intracellular and extracellular. Many ordinary bacilli as well.

Mice killed 1 day after challenge. 0 hr. preparations. Nearly all organisms were intracellular and in some stage of the L-cycle, small round red forms, red granular forms, filaments, and red and blue L-bodies. $24 \mathrm{hr}$. preparations. Increased number of all the various L-forms. Numerous fat pale blue bacilli also present.

Mice killed 7 days after challenge. $0 \mathrm{hr}$. and $24 \mathrm{hr}$. preparations. No organisms at all could be found.

In the immune animal 1 day after challenge, the results in the peritoneum were much the same as in the lung. However, after a week not even the $\mathbf{L}$-form could be found in the peritoneum. Possibly the conditions in the immune peritoneum are too unfavourable for any form of $\boldsymbol{H}$. pertussis to survive for long.

\section{DISCUSSION}

It has been suggested elsewhere (Wittler, 1951) that the small round red form is a resistant form of $\boldsymbol{H}$. pertussis. In vitro experiments showed that chilling, ageing, and the use of various chemicals promoted the transformation to $L$. The removal of these unfavourable environmental conditions resulted in the reversion from $L$ to bacillary form.

The methods employed in the present studies have made possible a clear demonstration of the morphology of $H$. pertussis as it occurs in vivo. These studies show that the L-form of $\boldsymbol{H}$. pertussis appears regularly in the mouse following intranasal and intraperitoneal infection. Furthermore, the L-form appears to be pathogenic, because most of the mice that received intranasal inoculation were ill or moribund when killed. Thus it seems unlikely that the small round red form is a degenerate type. The predominance of the L-form in immunized mice suggests that factors involved in host resistance may stimulate the transformation to $\mathbf{L}$ and that this transformation may assist the organism to escape destruction.

Work is now in progress on the virulence, toxicity, protective capacity, and many other aspects of the $\mathbf{L}$-form. It is hoped that these experiments will aid in the interpretation of the significance of the transformation.

This work was carried out under joint fellowships from the Lister Institute of Preventive Medicine, London, and the School of Medicine, Western Reserve University, Cleveland, Ohio, U.S.A. The author wishes to thank Dr E. Klieneberger-Nobel for the photography, and both Dr Klieneberger-Nobel and Mr A. F. B. Standfast for their constructive criticism and continued interest in this work.

\section{REFERENCES}

Dienes, L. \& Smith, W. E. (1944). The significance of pleomorphism in Bacteroides strains. J. Bact. 48, 125.

Dienes, L., Weinberger, H. J. \& Madoff, S. (1950). The transformation of typhoid bacilli into $L$ forms under various conditions. J. Bact. 59, 755.

KLIENEBERger, E. (1938). Pleuropneumonia organisms of diverse provenance: some results of an enquiry into methods of differentiation. J. Hyg., Camb.38, 458. 
Journal of General Microbiology, Vol. 6, Nos. 3 and 4
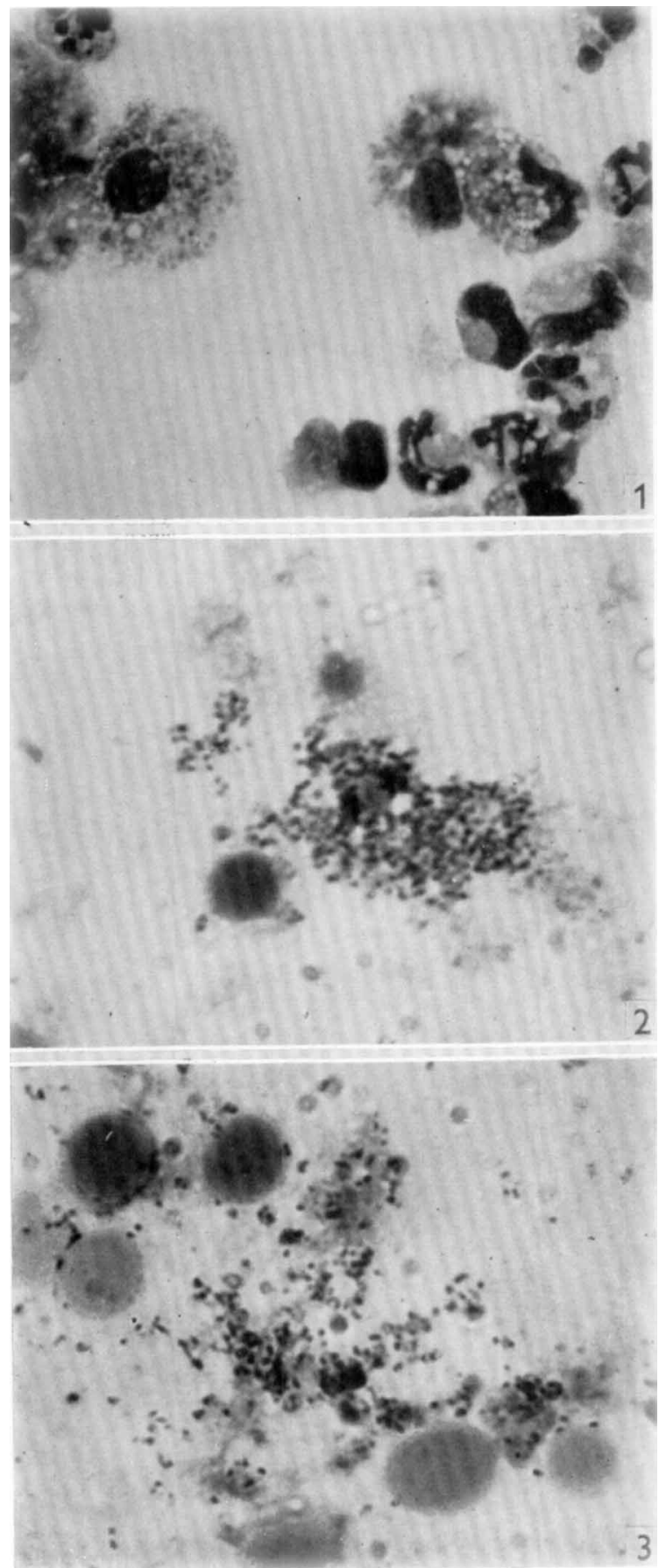

R. G. Wittlea-The L-form of H. Pertussis in the mouse. Plate $]$ 
Journal of General Microbiology, Vol. 6, Nos. 3 and 4
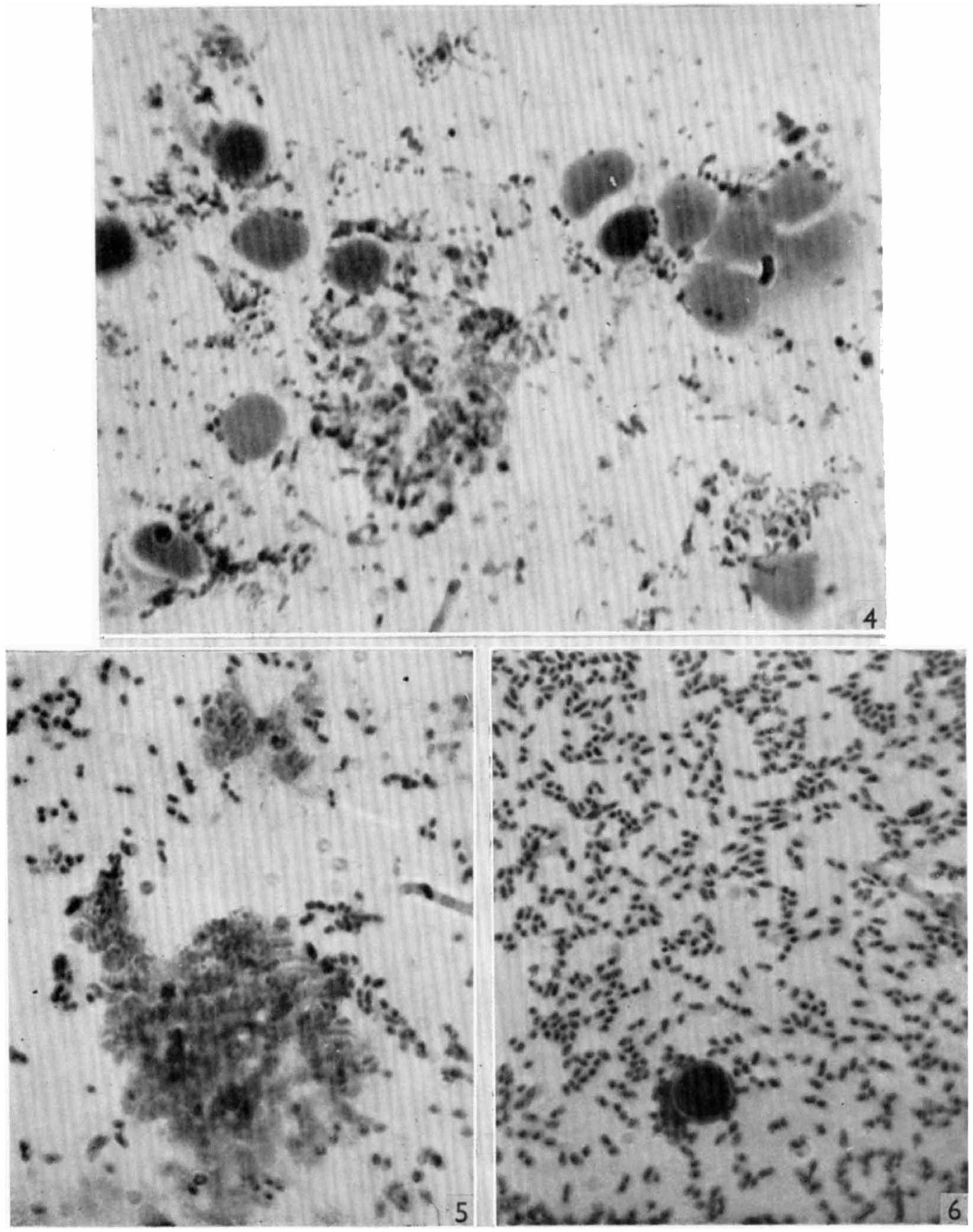

R. G. Wittler-The L-form of $H$. pertussis in the mouse. Plate 2 
KLIENEBErger-Nobel, E. (1949). Origin, development and significance of L-forms in bacterial cultures. J. gen. Microbiol. 3, 434.

KLIENEBERgEr-NobeL, E. (1950). Methods for the study of the cytology of bacteria and pleuropneumonia-like organisms. Quart. J. micr. Sci. 91, 340.

WitTler, R. G. (1951). The L-form of Haemophilus pertussis. J. gen. Microbiol. 5, 1024.

\section{EXPLANATION OF PLATES}

H. pertussis, strain 19939, isolated from a normal mouse inoculated intranasally with the L-form and killed 14 days later. Osmium tetroxide Giemsa impression preparations from BG plate cultures incubated at $\mathbf{3 5}^{\circ}$. Figs. $1-4$ treated for 3 min. at $55^{\circ}$ with $\mathrm{N}-\mathrm{HCl}$. Figs. 5 and 6 untreated.

$$
\begin{gathered}
\text { (Magnification } \times 2700 \text { throughout.) } \\
\text { PLATE } 1
\end{gathered}
$$

Fig. 1. 0 hr. preparation. Minute granular L-forms in the cytoplasm of leucocytes from the mouse lung.

Fig. 2. $3 \mathrm{hr}$. preparation. Small colony of L-forms next to an erythrocyte.

Fig. 3. $24 \mathrm{hr}$. preparation. Granular and amorphous L-forms. Several large bodies have appeared. Ring-shaped nuclear structure is characteristic of this stage of the L-cycle.

\section{Plate 2}

Fig. 4. $48 \mathrm{hr}$. preparation. A mass of amorphous L-material containing large and small bodies, granules, and a very few newly formed bacilli.

Fig. 5. $48 \mathrm{hr}$. preparation of first subculture. Large fat bacilli forming among masses of amorphous L-material.

Fig. 6. $24 \mathrm{hr}$. preparation of second subculture. Organisms have almost completely reverted to bacillary form.

(Received 5 October 1951) 